\title{
A Path Analysis on the Factors Associated with Birth Preparedness: Evidence from Wonogiri, Central Java
}

\author{
Hafari Fajria Nuril Ummah'), Eti Poncorini Pamungkasari²), Rita Benya Adriani3) \\ 1)Masters Program on Public Health, Universitas Sebelas Maret \\ 2)Department of Public Health, Faculty of Medicine, Universitas Sebelas Maret \\ 3)Department of Occupational Therapy, School of Health Polytechnics Surakarta
}

\begin{abstract}
Background: Birth preparedness and complication readiness is a strategy that encourages pregnant women, their families, and communities to effectively plan for births and deal with emergencies, if they occur. It is a key component of globally accepted safe motherhood programs. This study aimed to determine factors associated with birth preparedness in Wonogiri, Central Java.

Subjects and Method: This was a cross-sectional study carried out in Wonogiri, Central Java, from April to May 2018. A sample of 200 pregnant women was selected by cluster sampling. The dependent variable was birth preparedness. The independent variables were gestational age, parity, maternal education, maternal knowledge on birth sign, husband support, and health personnel role. The data were collected by questionnaire and analyzed by path analysis, run on Stata 13 .

Results: Birth preparedness was positively affected by good maternal knowledge on birth sign $(b=2.97 ; 95 \% \mathrm{CI}=0.10$ to $5.84 ; \mathrm{p}=0.043)$, husband support $(\mathrm{b}=5.06 ; 95 \% \mathrm{CI}=2.62$ to 7.51 ; $\mathrm{p}<0.001)$, and health personnel role $(\mathrm{b}=5.53 ; 95 \% \mathrm{CI}=2.95$ to $8.11 ; \mathrm{p}<0.001)$. Birth preparedness was indirectly affected by gestational age, maternal education, and parity.

Conclusion: Birth preparedness is positively affected by good maternal knowledge on birth sign, husband support, and health personnel role. Birth preparedness is indirectly affected by gestational age, maternal education, and parity.
\end{abstract}

Keywords: birth preparedness, gestational age, education, knowledge, husband support, health personnel role

\section{Correspondence:}

Hafari Fajria Nuril Ummah. Masters Program on Public Health, Universitas Sebelas Maret. Jl. Ir. Sutami No.36A, Surakarta 57126, Central Java. Email: mbakfari93@gmail.com.

Mobile:+6285712211401

\begin{tabular}{l}
\hline BACKGROUND \\
Maternal health is an indicator of a \\
country's health level. In the Sustainable \\
Development Goals (SDGs), one of the \\
indicators is the reduction in maternal \\
mortality (United Nation, 2015). Alema \\
(2016) states that in 2015, there were 216 \\
maternal deaths per 100,00o live births. \\
Almost all of these cases occur in \\
developing countries, even a third of them \\
occured in the Southeast Asia region \\
(WHO, 2016).
\end{tabular}

According to WHO, in 2015, Indonesia is at the fourth placein the ASEAN Maternal Mortality Rate and the sixth rank in the SEAR (South East Asian Region) region. SDKI in 2012 stated that there were $359 / 100,000$ live births. In fact, the national target is 77 / 100,000 live births according to SDGs. In 2015, in the province of Central Java, there were 619 cases of maternal deaths. This has shown a decrease in numbers compared to the previous year, namely in 2014 when there were 711 
maternal deaths (Central Java Provincial Health Office, 2015).

According to (WHO, 2016), cases of maternal death occur as a result of complications both during labor and after childbirth. In Indonesia, the top three causes of maternal death are still dominated by bleeding, hypertension in pregnancy, and also infection. Complications that occur in labor can actually be prevented. The prevention can be done with good planning as a form of labor readiness. Childbirth preparation is a form of maternal and family planning in dealing with childbirth including maternity facilities, service facilities, and things needed before, during and after the birth delivery process (JHPIEGO, 2004).

The high maternal mortality rate shows low prenatal and obstetric health care facilities including Antenatal Care (ANC) services (Husna, 2015), indicating that the frequency of ANC visits has a significant effect on maternal maternal readiness. The frequency of ANC visits is related to the role given by health personnel to pregnant women.

Mother's knowledge about labor signs and the danger signs in childbirth are very important in facing childbirth beside assistance from trained health personnel (Kuganab-Lem, Dogudugu and Canton, 2014). Mother's knowledge of the signs of childbirth and danger signs of childbirth are influenced by the level of maternal education. The maternal education level indirectly influences the mother's ability to absorb information about her pregnancy and childbirth (Fatmawati, 2015).

Emotional support of husband and family is an important factor for the success of developmental tasks in the labor process. In addition, the experience of facing labor or parity also affects the preparation of childbirth. Primigravida will usually be more anxious about their childbirth, while mothers who have maternity experience will be more calmed in facing childbirth (Husna, 2015).

In Wonogiri District, 15 cases of maternal death were found placing it as one of the three districts in the Surakarta Residency area with the highest AKI (Central Java Provincial Health Office, 2015). Most of the causes of death are due to the unpreparedness of childbirth from both mother and family. Through this research, researchers want to explore more about the extent of preparedness of pregnant women in facing childbirth, thus increasing the possibility of reducing complications that occur during labor.

\section{SUBJECTS AND METHOD \\ 1. Study Design \\ This was an analytic observational study with a cross sectional design. The study was conducted in Wonogiri, Central Java, from April to May 2018.}

\section{Population and Samples}

The study population was pregnant women in Wonogiri, Central Java. A sample of 200 pregnant women was selected by simple random sampling.

\section{Study Variables}

The dependent variable was birth preparedness. Independent variables were gestational age, parity, education, knowledge on birth sign, husband support, and health personnel role.

\section{Operational Definition of Variables}

Birth preparedness was defined as maternal ability to face childbirth, both physically and psychologically. The data were measured by questionnaire. The measurement scale was continuous, but for the purpose of data analysis, it was transformed into dichotomous, coded o for o poor and 1 for good. 
Maternal age was defined as pregnant women age at the time of the study. The data were measured by questionnaire. The measurement scale was continuous, but for the purpose of data analysis, it was transformed into dichotomous, coded o for $<20$ years and 1 for 20-35 years.

Parity was defined as the number of pregnancies that produce a fetus that is able to life outside the uterus ( 28 weeks). The data were measured by questionnaire. The measurement scale was continuous, but for the purpose of data analysis, it was transformed into dichotomous, coded $\mathrm{O}$ for primiparous and 1 for multiparous.

Maternal education was defined as the last level of formal education completed by a mother. The data were measured by questionnaire. The measurement scale was categorical, coded o for <senior high school and 1 for $\geq$ senior high school.

Maternal knowledge on birth sign was defined as knowledge that mothers have related to the signs of childbirth. The data were measured by questionnaire. The measurement scale was continuous, but for the purpose of data analysis, it was transformed into dichotomous, coded o for poor and 1 for good.

Husband support was defined as the support given by the husband including emotional, instrumental, appraisal, and informational support. The data were measured by questionnaire. The measurement scale was continuous, but for the purpose of data analysis, it was transformed into dichotomous, coded $\mathrm{o}$ for weak and 1 for strong.

Health personnel role was defined as counseling given by health personnel to pregnant women about birth preparation. The data were measured by questionnaire. The measurement scale was continuous, but for the purpose of data analysis, it was transformed into dichotomous, coded o for weak and 1 for strong.

\section{Data Analysis}

The data were analyzed by path analysis run on Stata 13 to determine the relationship of gestational age, parity, education, knowledge on birth sign, husband support, and health personnel role on birth preparedness, both directly and indirectly.

\section{Research Ethics}

The research ethical clearance was obtained from the Research Ethics Committee at Dr. Moewardi Hospital, Surakarta, Central Java, Indonesia. Research ethics included issues such as informed consent, anonymity, confidentiality, and ethical clearance.

\begin{tabular}{|c|c|c|}
\hline \multicolumn{3}{|c|}{ RESULTS } \\
\hline \multicolumn{3}{|c|}{$\begin{array}{l}\text { 1. Univariate Analysis } \\
\text { Table 1. Univariate Analysis }\end{array}$} \\
\hline Variable & $\mathbf{n}$ & (\%) \\
\hline \multicolumn{3}{|l|}{ Maternal Age } \\
\hline$<20$ years & 26 & 13 \\
\hline \multirow{2}{*}{\multicolumn{3}{|c|}{ Maternal occupation }} \\
\hline & & \\
\hline Not working & 104 & 52 \\
\hline Working & 96 & 48 \\
\hline \multicolumn{3}{|l|}{ Family income } \\
\hline$<$ Minimum wage & 68 & 34 \\
\hline$\geq$ Minimum wage & 132 & 66 \\
\hline \multicolumn{3}{|l|}{ Birth preparedness } \\
\hline Poor & 32 & 16 \\
\hline Good & 168 & 84 \\
\hline \multicolumn{3}{|l|}{ Gestational age } \\
\hline TM I & 44 & 22 \\
\hline TM II/III & 156 & 78 \\
\hline \multicolumn{3}{|l|}{ Parity } \\
\hline Primiparous & 88 & 44 \\
\hline Multiparous & 112 & 56 \\
\hline \multicolumn{3}{|l|}{ Maternal education } \\
\hline$<$ senior high school & 47 & 23.5 \\
\hline$\geq$ senior high school & 153 & 76.5 \\
\hline \multicolumn{3}{|c|}{ Knowledge on birth sign } \\
\hline Poor & 26 & 13 \\
\hline Good & 174 & 87 \\
\hline \multicolumn{3}{|l|}{ Husband Support } \\
\hline Weak & 31 & 15.5 \\
\hline Strong & 169 & 74.5 \\
\hline \multicolumn{3}{|c|}{ Health personnel role } \\
\hline Weak & 28 & 14 \\
\hline Strong & 172 & 86 \\
\hline
\end{tabular}


Table 1 shows the results of study subject characteristics. Most of the study subjects were at reproductive age (20-35 years) (87\%), and received strong husband support (169, 84.5\%).

As many as 112 mothers (56\%) were multiparous, 104 mothers (52\%) were working at home, and 153 mothers (76.5\%) had education level $\geq$ senior high school.
Mother with good birth preparedness was 168 (84\%). Mother with family income $\geq$ minimum wage was 132 (66\%). Strong health personnel role was 172 (86\%).

\section{Bivariate Analysis}

The results of bivariate analysis can be seen in table 2.

Table 2. Bivariate Analysis on the determinants of birth preparedness

\begin{tabular}{|c|c|c|c|c|c|c|c|c|c|}
\hline \multirow{2}{*}{ Independent Variable } & \multicolumn{2}{|c|}{ No } & \multicolumn{2}{|c|}{ Yes } & \multicolumn{2}{|c|}{ Total } & \multirow{2}{*}{ OR } & \multirow{2}{*}{$\begin{array}{c}\mathbf{9 5 \%} \\
\text { CI }\end{array}$} & \multirow[b]{2}{*}{$\mathbf{p}$} \\
\hline & $n=32$ & $\%$ & $n=168$ & $\%$ & $\mathbf{n}=\mathbf{2 0 0}$ & \% & & & \\
\hline Gestational age & & & & & & & & & \\
\hline TM I & 19 & 43.2 & 25 & 56.8 & 44 & 100 & 0.30 & 2.19 to & $<0.001$ \\
\hline TM II/III & 13 & 8.3 & 143 & 91.7 & 156 & 100 & & & \\
\hline Parity & & & & & & & & & \\
\hline Primiparous & 32 & 36.4 & 56 & 63.6 & 88 & 100 & 0.57 & $\begin{array}{l}0.20 \\
\text { to } 3.28\end{array}$ & 0.027 \\
\hline Multiparous & o & o & 112 & 100 & 112 & 100 & & & \\
\hline Education & & & & & & & & & \\
\hline Low & 20 & 42.6 & 27 & 57.4 & 47 & 100 & 0.42 & 6.18 to & $<0.001$ \\
\hline High & 12 & 7.8 & 141 & 92.2 & 153 & 100 & & & \\
\hline $\begin{array}{l}\text { Knowledge on birth } \\
\text { sign }\end{array}$ & & & & & & & & & \\
\hline Do not understand & 22 & 84.6 & 4 & 15.4 & 26 & 100 & 0.77 & 1.12 to & $<0.001$ \\
\hline Understand & 10 & 5.7 & 164 & $94 \cdot 3$ & 174 & 100 & & & \\
\hline Husband Support & & & & & & & & 0.09 & \\
\hline Weak & 26 & 83.9 & 5 & 16.1 & 31 & 100 & 067 & to & $<0.001$ \\
\hline Strong & 6 & 3.6 & 163 & 96.4 & 169 & 100 & 0.67 & 0.28 & \\
\hline Health personnel role & & & & & & & & & \\
\hline $\begin{array}{l}\text { Weak } \\
\text { Strong }\end{array}$ & $\begin{array}{c}25 \\
7\end{array}$ & $\begin{array}{c}89.3 \\
4.1\end{array}$ & $\begin{array}{c}3 \\
165\end{array}$ & $\begin{array}{l}10.7 \\
95.9\end{array}$ & $\begin{array}{c}28 \\
172\end{array}$ & $\begin{array}{l}100 \\
100\end{array}$ & 0.74 & $\begin{array}{l}1.87 \text { to } \\
4.38\end{array}$ & $<0.001$ \\
\hline
\end{tabular}

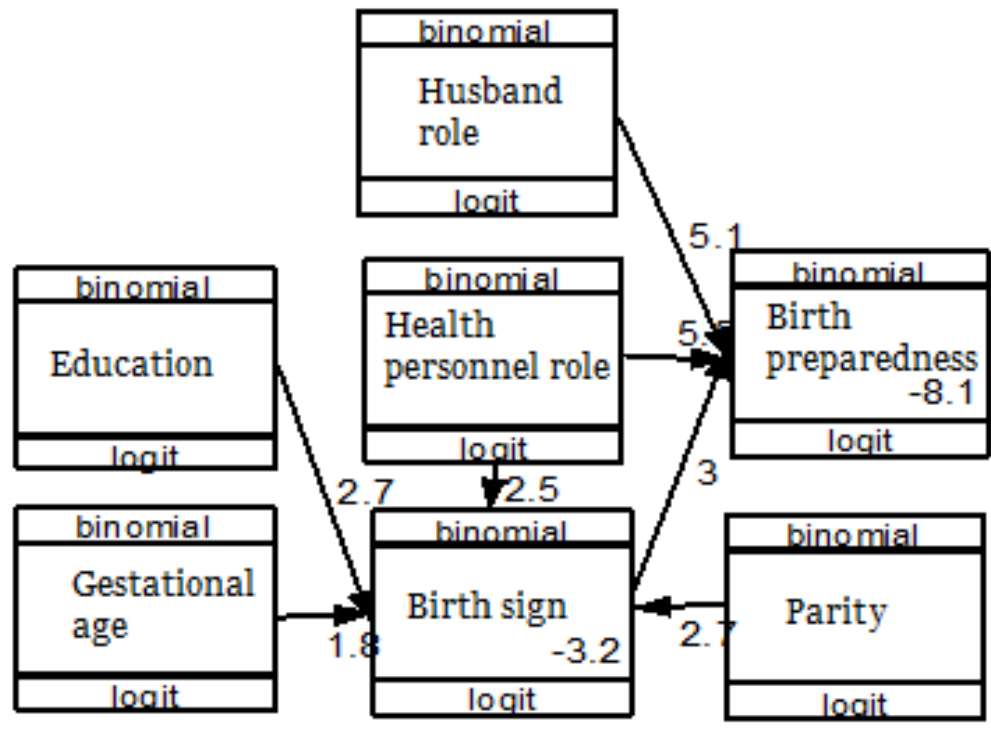

Figure1. Structural Model of Path Analysis with Estimation 
Ummah et al./ A Path Analysis on the Factors Associated with Birth Preparedness

Table 3. The Results of Path Analysis

\begin{tabular}{|c|c|c|c|c|c|c|}
\hline \multirow{2}{*}{$\begin{array}{c}\text { Independent } \\
\text { variable }\end{array}$} & & \multirow[b]{2}{*}{ Dependent variable } & \multirow[b]{2}{*}{ b } & \multicolumn{2}{|c|}{ 95\% CI } & \multirow[b]{2}{*}{$\mathbf{p}$} \\
\hline & & & & $\begin{array}{l}\text { Upper } \\
\text { Limit }\end{array}$ & $\begin{array}{c}\text { Lower } \\
\text { Limit }\end{array}$ & \\
\hline \multicolumn{7}{|l|}{ Direct Effect } \\
\hline Birth preparedness & $\leftarrow$ & Birth sign & 2.97 & 0.10 & 5.84 & $<0.001$ \\
\hline Birth preparedness & $\leftarrow$ & Husband support & 5.06 & 2.62 & $7 \cdot 51$ & 0.043 \\
\hline Birth preparedness & $\leftarrow$ & Health personnel role & $5 \cdot 53$ & 2.95 & 8.11 & $<0.001$ \\
\hline \multicolumn{7}{|l|}{ Indirect Effect } \\
\hline Birth sign & $\leftarrow$ & Gestational age & 1.76 & 0.36 & 3.16 & 0.014 \\
\hline Birth sign & $\leftarrow$ & Parity & 2.73 & 0.47 & 4.98 & 0.018 \\
\hline Birth sign & $\leftarrow$ & Education & 2.67 & 1.26 & 4.09 & $<0.001$ \\
\hline Birth sign & $\leftarrow$ & Health personnel role & 2.46 & 1.07 & 3.85 & 0.001 \\
\hline
\end{tabular}

\section{The results of path analysis}

Path analysis model in this study was depicted in Figure 1. The results of path analysis were showed in Table 3 . Based on table 3, knowledge on birth sign, husband support, and health personnel role were directly and positively associated with birth preparedness.

Birth preparedness was directly and positively affected by knowledge on birth sign $(b=2.97 ; 95 \% \quad C I=0.10$ to 5.84 ; $\mathrm{p}<0.001)$, husband support $(\mathrm{b}=5.06 ; 95 \%$ $\mathrm{CI}=2.62$ to $7.51 ; \mathrm{p}=0.043$ ), health personnel role $(b=5.53 ; 95 \% \mathrm{CI}=2.95$ to 8.11 ; $\mathrm{p}<0.001)$.

Birth preparedness was indirectly affected by education, gestational age, parity, and health personnel role through knowledge about birth sign.

Knowledge about birth sign was positively affected by education $(b=2.67$; 95\% CI $=1.26$ to $4.09 ; \mathrm{p}<0.001$ ), gestational age $(b=1.76 ; 95 \% \mathrm{CI}=0.36$ to $3.16 ; \mathrm{p}=$ $0.014)$, parity $(b=2.73 ; 95 \% \mathrm{CI}=0.47$ to 4.98; $\mathrm{p}=0.018$ ), and health personnel role $(b=2.46 ; 95 \% \mathrm{CI}=1.07$ to $3.85 ; \mathrm{p}=0.001)$.

\section{DISCUSSIONS}

\section{The association between know- ledge about birth sign on birth preparedness}

The result of this study showed that there was an association between knowledge of birth sign and birth preparedness. High maternal knowledge about birth sign increased maternal birth preparedness.

The results of this study is consistent with a study by Nkowo (2017), which stated that knowledge of birth sign, risk factor, and complications during labor are important to reduce morbidity and mortality among mother and infant.

\section{The association between husband support on birth preparedness}

The result of this study showed that there was a relationship between husband support and birth preparedness. Strong husband support increased maternal birth preparedness.

The results of this study is consistent with a study by Maluka and Peneza (2018), which stated pregnant women need the support from their husband in the form of assistance, especially in the early stage of pregnancy. In addition, husband role was not only in the fulfillment of financial needs, but also as a decision maker during birth labor.

\section{The association between health personnel role on birth prepared- ness}

The result of this study showed that there was an association between health personnel role and birth preparedness. Health personnel role was directly and positively associated with birth preparedness. Preg- 
nant mothers who got good counseling and health service about pregnancy and birth delivery from health personnel were 5.53 times more prepared to face birth delivery.

Health personnel role was also indirectly associated with birth preparedness through maternal knowledge. Strong health personnel role increased maternal knowledge about birth sign.

The results of this study is consistent with a study by Avortri (2018), which stated that pregnant women desperately needed the presence of health personnel, especially health personnel who were qualified and could cooperate with patient. Health personnel played a role in providing information needed by mother during pregnancy and birth delivery.

Andriani (2016) reported that the existence of health personnel role through maternity class can reduce the risk of maternal anxiety and pain during labor.

\section{The association between gesta- tional age on birth preparedness}

The result of this study showed that there was an association between gestational age was indirectly associated with birth preparedness through knowledge about birth signs. Higher gestational age increased the likelihood of maternal knowledge about birth sign.

The results of this study is consistent with a study by Choi (2018), which stated that pregnant women who have entered the middle to final stage of their pregnancy tend to experienced anxiety compared to pregnant women in the early stage of pregnancy. However, anxiety encouraged pregnant women to prepare the delivery process by seeking information about pregnancy and labor, and preparing themselves for risks that might occur during pregnancy and labor.

\section{The association between parity on birth preparedness}

The result of this study showed that there was an indirect association between parity and birth preparedness through maternal knowledge about birth sign. Multiparous mother more likely to had better knowledge about birth sign than primiparous mother.

The results of this study is consistent with a study by $\mathrm{Xu}$ et al. (2018), which stated that parity is a factors that affects pregnancy and labor process. Multiparous mother would be able to prepare themselves both physically and mentally during pregnancy and birth labor.

Parity also affected postpartum anxiety and depression. According to Nisa (2018), multiparous lowered the risk of anxiety during labor and postpartum depression.

\section{The association between education on birth preparedness}

The result of analysis showed that there was an indirect relationship between education and birth preparedness through knowledge about birth signs. Table 3 showed a statistically significant relationship with the path analysis coefficient score of 2.67 and the score of $\mathrm{p}=0.000$. This mean that pregnant women who were highly educated were 2.67 times more prepared than mothers with low education.

This statement was in line with a study by Izadi (2016), which stated thatwomen or pregnant women with good education tend to be able to determine plannings for their families (family planning), one of them was deciding where to give birth and who the helper was. In addition, highly-educated mothers have the awareness to maintain their pregnancy and prepare for delivery by seeking information and other needs. 


\section{REFERENCES}

Alkema L, Doris C, Daniel, et al. (2016). Global, regional, and national levels and trends in maternal mortality between 1990 and 2015, with scenario-based projections to 2030: a systematic analysis by the UN Maternal Mortality Estimation Inter-Agency Group. The Lancet, 387(10017): 462474.

Andriani Y, Supriyadi HR, Okid PA (2016). Effectiveness of Pregnant Woman Class in the Prevention of Pregnancy Anemia in Banyuwangi, East Java. Journal of Maternal and Child Health, 1(4): 230-241.

Arifin A, Rina K, Sefti R (2015). Hubungan Dukungan Keluarga Dengan Kecemasan Ibu Hamil Menghadapi Proses Persalinan Di Puskesmas Budilatama Kecamatan Gadung Kabupaten Buol, Propinsi Sulawesi Tengah. eJournal Keperawatan (e-Kp) Universitas Sam Ratulangi Manado, 3(2).

August F, Pembe AB, Kayombo E, Mbekenga C, Axemo P, Dari E (2015). Birth preparedness and complication readiness - a qualitative study among community members in rural Tanzania. Glob Health Action. 12(8): 26922. doi: 10.3402/gha.v8.26922

Avortri GS, Lebitsi MM (2018). Women's perspective of facility-based childbirth services in Ghana: A qualitative study. African Journal of Primary Health Care \& Family Medicine 10(1): a1434

Choi, Hyun Jin (2018). How Fine Particulate Matter Modifies Preterm Birth Risks in Korea. Walden Dissertations and Doctoral Studies, Walden University.

Dinas Kesehatan Provinsi Jawa Tengah (2015). Profil Kesehatan Provinsi Jawa Tengah Tahun 2015.
Haobijam J, Sharma U, David S (2010). An exploratory study to assess the Family support and its effect on Outcome of Pregnancy in terms of Maternal and Neonatal health in a selected Hospital, Ludhiana Punjab. Nurs Midwifery Res J. 6(4).

Harun HM, Zulkifli A, Ansariadi A (2013). The Relations of Characteristics and Maternal Behavior with Labor Status in Coastal Areas Tallo Subdistrict Makassar. Bagian Epidemiologi Fakultas Kesehatan Masyarakat Universitas Hasanuddin.

Husna DA, Sundari (2015). Persiapan Persalinan Ibu Hamil Ditinjau Dari Jumlah Persalinan Dan Jumlah Kunjungan Kehamilan. Dinamika Kesehatan Jurnal Kebidanan dan Keperawatan, 6(1): 2015.

Igberase G (2012). Harmful cultural practices and reproductive health in Nigeria. Cont J Trop Med. 6(1):27.

Izadi V, Vahid Z, Mehri S, et al. (2018). Investigation of factors affecting the tendency to choose the type of delivery in pregnant women referring to hospitals of Ardabil Province in 2016. J Family Med Prim Care. 7:406-13.

JHPIEGO (2001). Maternal and Neonatal Health Program. Birth Preparedness and Complication Readiness: A Matrix of Shared Responsibilities. Baltimore: JHPIEGO.

(2004). Maternal and neonatal health. Monitoring birth preparedness and complication readiness, tools and indicators for maternal and newborn health. Johns Hopkins, Bloomberg school of Public Health, Center for communication programs, Family Care International.

Jing XU, Junhu W, Shuxia X, et al. (2018). The Effects of Childbirth Age on Maternal and Infant Outcomes in 
Pregnant Women. Iranian Journal of Public Health. 47(6):788-793.

Kabakyenga JK, Östergren PO, Turyakira E, Pettersson KO (2012). Influence of birth preparedness, decision-making on location of birth and assistance by skilled birth attendants among women in south-western Uganda. PloS One. 7(4):e35747 doi: 10.1371/journal.pone.0035747

Kementerian Kesehatan RI (2014). Pusat Data dan Informasi. Jakarta

Kibballi MA (2017). Birth preparedness and complication readiness among the women beneficiaries of selected rural primary health centers of Dakshina Kannada district, Karnataka, India. PLoS One. 12(8): e0183739 doi: 10.1371/journal.pone.0183739

Kuganab-em RB, Dogudugu R, Kanton L (2015). Birth preparedness and complication readiness: a study of postpartum women in a rural district of Ghana. SciAcad Publ. 4: 225-38.

Maluka SO, Apollonia KP (2018). Perceptions on male involvement in pregnancy and childbirth in Masasi District, Tanzania: a qualitative study. BMC Pregnancy and Childbirth.
Nisa SMK, Supriyadi HR, Bhisma M (2018). Psychosocial Factors Associated with Anxiety and Delivery Pain. Journal of Maternal and Child Health, 3(1): 44-58.

Nkomo, Pamella B (2017). Morbidity in women with placenta abruption: a descriptive prospective study. WIReDSpace, University of Witwatersrand

Soubeiga D, Lise G, Marie AH, Mira J (2014). Birth Preparedness and Complication Readiness (BPCR) interventions to reduce maternal and neonatal mortality in developing countries: systematic review and meta-analysis. BMC Pregnancy Childbirth.14: 129 doi: 10.1186/1471-2393-14-129.

Tokhi M, Comrie-Thomson L, Davis J, Portela A, Chersich M, Luchters S (2018). Involving men to improve maternal and newborn health: A systematic review of the effectiveness of interventions. PLoS ONE 13(1): eo191620. https://doi.org/10.1371/journal.pone.0191620 .

WHO (2016). Maternal mortality. Diakses pada Kamis 26 Juli 2018 